\title{
Financialization directing strategy
}

\author{
Tord Andersson \\ Colin Haslam * \\ Edward Lee \\ Nick Tsitsianis

\section{Centre for Research in Finance and Accounting (CRiFA) University of Hertfordshire}

\section{Draft Paper}

Please do not quote without author's permission

\begin{abstract}
This paper constructs an account of how financialization is directing strategy in the S\&P 500 . Financialization describes how changes in US accounting regulations require firms to account for the market value of capital market transactions where corporate strategy is not simply concerned with delivering value creation but also reacting to value absorption in an era of shareholder value. Financialization is directing strategy and arbitrage to modify stakeholder financial settlements where an increased share of income is extracted as surplus cash and more of this cash from operations is being distributed to shareholders. Share buy-backs account for a substantial increase in the share of corporate cash distributed to shareholders in the S\&P 500 which, we argue, reflects a strategic process of value creation and value absorption.
\end{abstract}

Key words: Financialization, strategy, market for corporate control, fair value reporting.

\footnotetext{
* Contact: Professor Colin Haslam

c.j.haslam@herts.ac.uk
} 


\section{Introduction}

In this paper we argue that a process of financialization is directing strategy in an era of shareholder value. We employ the descriptor 'financialization' as a way of 'making sense out of what is going on around us' (Martin, 2002). A narrow use of the term 'financialization' can be used to describe the possibilities and limitations of a sector matrix, as opposed to industry and sector specific strategic moves where, for example, financial services are bolted on to a firms activity mix in an attempt to boost return on capital employed and wealth accumulation for shareholders. A broader use of the term 'financialization' has been employed to reveal, how: managerial behaviour and culture, corporate governance, stakeholder interests, firm performance, national economic competitiveness and the distribution of income and wealth that are modified by the demands of finance capital (Deeg et al 2006, Fligstein 2004, Froud et al, 2006, Rossman et al, 2006, Stockhammer, 2004).

In this paper we employ the term 'financialization' to describe the implications of combining an active market for corporate control with fair value reporting where corporate-capital market transactions are now accounted for at market value in the US. Our argument is that 'financialization' is directing corporate strategy because managers are not only under pressure to extract additional cash out of income but also distribute a greater share of corporate cash to increase the probability of enhancing value creation and accommodate value absorption for shareholders.

Orthodox accounts of corporate sector 'financialization' are generally concerned with the possibilities and limitations of strategy and systems of governance within a value creation framework. On the one hand it is argued that strategy for value creation coupled with appropriate regulatory and managerial incentives can both sustain corporate performance and transform national economic competitiveness (Jensen, 1993, Rappaport, 1986, Stewart, 1991). On the other hand critics suggest that concentrating on value creation for shareholders is problematic because the foundations of corporate financial success are dependent upon the commitment of all stakeholders, where collective dynamics matter and investment in product and process renewal are required to sustain innovation and competitiveness (Freeman, 1984, Porter, 1980, Hamel and Stern, 1995, O’Sullivan, 2000). 
This paper is not specifically concerned with whether appropriate forms of strategy and corporate governance can transform corporate performance and sustain national economic competitiveness. The objective of this paper is to construct a complementary account of how financialization is directing strategy and financial arbitrage, which in turn are prompted by shareholder demand(s) for value creation and value absorption in the US corporate sector.

The argument is that the orthodox literature on strategy for shareholder value creation can be described as sharing a common organising schematic of: process $\rightarrow$ elements $\rightarrow$ direction. The process of value creation runs in a left to right direction and includes elements of: strategy formulation (represented as narratives and numbers), financial arbitrage (to modify stakeholder contracts/settlements), governance and incentives which encourage managers to strengthen financials which, in turn, through the prism of corporate valuation metrics, delivers market value (MV) for shareholders. In this model of strategy for value creation the corporate sector is effectively decoupled from the secondary trading activities of the stock market and wealth accumulation.

There has always been an active market for corporate control in the US but this is now coupled to 'fair value' accounting with the result that wealth accumulation, in the capital market, is being absorbed onto corporate sector balance sheets. If we accept that corporate financials are modified by a process of value absorption it is also necessary to add additional polarity into the conventional value creating model. Because value absorption not only impacts on reported corporate financials it also forces additional stakeholder arbitrage and modifies corporate strategy. In the US there is an active market for corporate control with over $\$ 10$ trillion spent on M\&A deals since 1996 which is equivalent to roughly turning over the current market value of the S\&P 500 in ten years. In an earlier period it was possible to avoid accounting for the market value of these acquisitions when the accounts of the two companies were simply 'pooled'. However, this has changed with revisions to SFAS 141 (see FASB, 2001) which requires the US corporate sector to account for the market value, or 'fair value', of acquisitions. Now that these deals are accounted for at their fair value this is forcing the corporate sector to absorb wealth accumulation into financial accounts. As MV is absorbed onto corporate sector balance sheets capitalization generally inflates ahead of cash earnings increasing value at risk (VAR) (Andersson et al, 2007, 2008). Value absorption thus forces managers to extend the share of cash extracted out of income and lever this extra cash to finance share buy-backs which, in turn, helps to contain shareholder VAR. Stakeholder 
contracts are up for renegotiation and arbitrage across product, procurement, labour and capital markets to increase cash extraction and also modify the pattern of cash distribution towards shareholders (Andersson et al 2008).

This change in perspective has consequences for the way in which we construct narratives about strategy, governance, financial performance and value. Financialization is driving strategy because the process and elements are operating simultaneously in both a left to right (value creation) and right to left (value absorbing) direction. Corporate financials not only reflect current income and expenditure circuits they also embody the product of capital market wealth accumulation when corporate-capital market transactions are accounted for at market value. The spheres of current cash earnings and wealth accumulation are now increasingly blended in corporate sector accounts. Financialization is directing corporate strategy because value creation and value absorption adjust managerial behaviour, governance priorities and stakeholder settlements (Andersson et al, 2008). Significantly value absorption distorts conventional financial performance metrics, such as Profit and Cash ROCE, restricting the purchase of critical narratives and positivist accounts which construct their arguments within an orthodox left to right framework of analysis.

The next section of this article reviews the literature on strategy for value creation which we schematically represent as a process containing specific elements operating along a continuum which runs in a left to right direction. We then construct a financial framework which is employed to reveal how financialization is directing strategy, as value creation and value absorption, and how this is modifying the share of cash extracted out of income and pattern of cash distribution in the S\&P 500. In the final section we illustrate how financialization is directing strategy in Procter and Gamble where stakeholder arbitrage has increased the share of income retained as surplus cash and modified the pattern of cash distribution to sustain value creation and accommodate value absorption for shareholders. 


\section{Strategy as value creation}

In an era of shareholder value the purpose of corporate strategy is to enhance operating financials which in turn generates the possibility for extending wealth accumulation for shareholders in the capital market as market value (MV). We start by reviewing the orthodox academic literature on shareholder value creation and situate this in an organising schematic: where the process and elements, within the value creating process, run in a left to right direction. In figure 1 strategy formulation, contractual renegotiation, stakeholder arbitrage and managerial incentives feed into corporate financial performance indicators and associated narratives which inform capital market valuation(s). This organising schematic of strategy as a value creating process is set out in figure 1 below:

Figure 1: Strategy for value creation: process, elements, direction

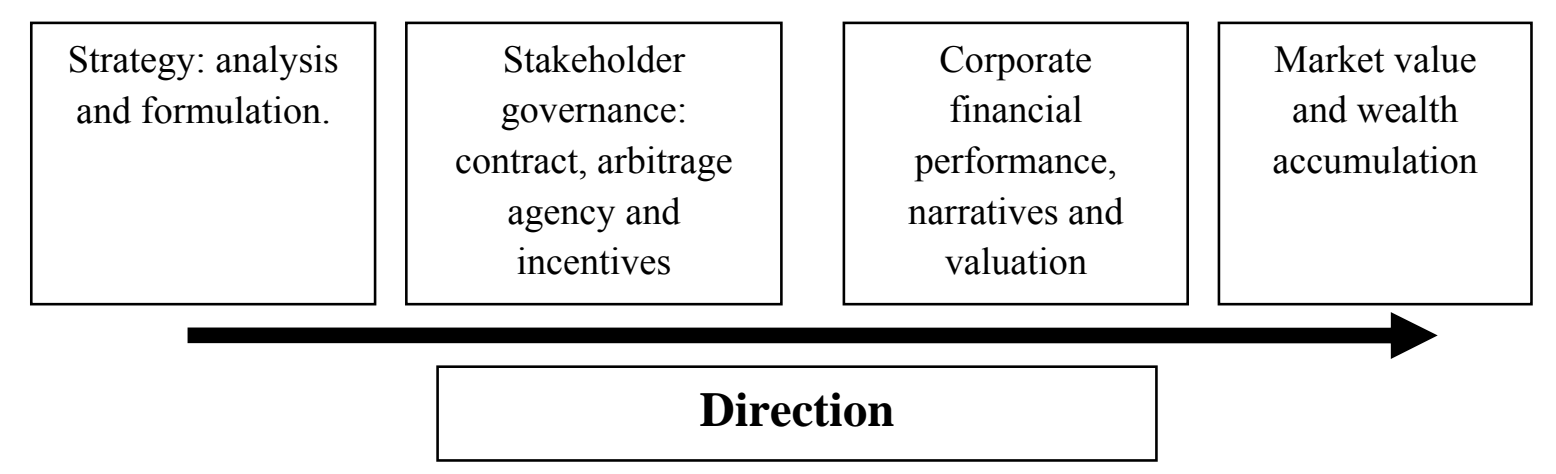

Porter (1980), Prahalad at al (1990) and Kay (1993), construct models of strategy formulation which emphasise the importance of industry, product market positioning and the need to dynamically manage resources and capabilities for innovation and thus competitiveness. Changes in policy and strategic priority need to be articulated across a cobweb of formal and informal contractual relations with stakeholders internal and external to the firm (Coase, 1937, Williamson, 1975). Formal and informal contractual relations with stakeholders may reduce financial risk but there is still the issue of uncertainty which can unsettle corporate financial performance (Knight, 1921). The impossibility of complete information and 
insurance against uncertainty ensures that financial expectations and outcomes will vary. In these circumstances formal and informal contractual obligations are malleable and arbitrage employed to constantly modify stakeholder settlements. This process of contractual renegotiation is coupled to managerial incentives which are aimed at securing appropriate financial outcomes, from corporate restructuring, for shareholder value (Rappaport, 1986, Froud et al 2000, Andersson et al, 2007)

This implies that stakeholder contracts and their renegotiation play an important part in establishing connections between the formulation and execution of strategy and financial expectations, performance, and thus market value. However, rather than focus on contracts from a market and exchange perspective, one needs to look at stakeholder contracts in relation to production and in this context it is possible to comprehend the criticisms of the theory of the firm (see Coase 1991, Simon 1991) and it's concern with contractual relations in terms of exchange and markets. As a result the organisation and the execution of production among and within firms, for the benefit of the household, have been neglected. Coase also notes (Williamson et al 1993) that the financing of the firm "by acquiring, leasing and borrowing capital was not examined" in his paper 'The Nature of the Firm'. This implies that the orthodox economists have neglected the main activity of the firm, namely running a business, and need to go beyond an explanation of "why there were firms?"

Cowling et al (1998) observe that the firm is a locus for the coordination of production where the crucial distinguishing feature of transactions within a corporation is that they are the subject of strategic decision-making from one centre. As such the firm is primarily about strategic decision-making, not about a set of market transactions and by shifting the analytical focus away from an excessive concern for property rights to one where power and distributional considerations are at the centre, a theory of the firm needs to consider the role played by strategic decision makers, uncertainty and transaction costs in addition to pure cost in the context of production.

However what happens between the purchase of factors of production and the sale of goods that are produced by the firm has been is largely ignored (Coase, 1991). This comment is important because Coase and others have contributed to view of the firm as a set of interrelated contracts among various factors: input suppliers and the purchasers of the final product (Cornell et al 1987). From this perspective the firm's claimants go beyond 
stockholders and bondholders to include customers, suppliers, providers of complementary services and products, distributors and employees. Despite the view of the firm as a contractual coalition that includes investor and non-investor stakeholders, the traditional emphasis in corporate finance has been on the firm's investors, and their evaluation of and responses to the firm's changing economic circumstances. It is Cornell et al's (1987) belief that stakeholders other than investors and management play an important role in financial policy and constitute a vital link between corporate strategy and corporate finance.

Rappaport (1986) argues that the link between competitive strategy analysis and the shareholder value metrics is through the value chain (Porter 1985) and cash flow fundamentals. His argument is that managers need to understand the behaviour of costs as well as the basis for differentiation, which can be done by disaggregating the firm into its constituent strategic activities. Rappaport also argues that "management is often characterised as balancing the interest of various corporate constituents, such as employees, customers, suppliers, debt, and stockholders" (ibid p 59). This argument aligns with that provided by Treynor (1981), which is that the firm's existence depends on the financial relationship with these stakeholders and the ability to satisfy these claims.

The lack of integration between strategy and finance, as observed above, may be related to the fact that there is still a search for an integrated financial 'strategic theory of the firm' (see Rumfelt et al, 1994). Researchers have suggested several theories of the firm as they moved towards 'a strategic theory of the firm', but economists have been very critical of these approaches (Phelan et al 2000).

In order to make visible how strategy and stakeholder arbitrage modify the pattern of cash extraction and distribution to stakeholders to (possibly) boost market valuation we employ an accounting framework to reveals stakeholder claims against income and cash. A general criticism of research that employs accounting numbers is concerned with how these numbers are socially constructed and technically malleable especially when accounting standards permit a wide variety of treatments, judgements and classifications (Cutler et al, 1978). Financial numbers are malleable, for example, the classification of expenses by function will always be subject to arbitrary judgements about the allocation of expenses to particular categories but, to a large extent, this can be mitigated where a financial description of firm activity is constructed out of a nature of expenses approach and where the focus is on 
corporate cash rather than profit. Rather than dispose of the accounting numbers it is possible to employ accounting numbers to help construct alternative perspectives and narratives about financialization, as value creation and value absorption, and how this is directing strategy.

In figure 2 we construct a nature of expenses financial model of the firm which reproduces the traditional pyramid structure of accounting ratios which can be found in most basic accounting textbooks. At the top of the pyramid is the cash return on capital employed (CFROCE) which is an important indicator because cash and capital employed figure in most shareholder value performance and valuation metrics which focus on discounting corporate cash and expected growth rates into current MV. This ratio can technically be deconstructed into two constituent elements: the cash residual and capital employed. The cash residual, in turn, is found after deducing all external procurements costs and employee compensation from total income and the capital employed results from aggregating long-term debt and shareholder equity (excluding short-term debt and minority interests). The financial model described in figure 1 can also be employed to reveal stakeholder interests in: final consumption, procurement from suppliers, employee expenses, and cash distribution to government (tax), banks (net interest), shareholders (dividends, cash paid for acquisitions and share buy-backs) and capital expenditure for corporate product and process renewal. Over a period of time changes in the share of cash in income and pattern of cash distribution reveal the extent to which stakeholder settlements, embodied in the financial numbers, are being modified.

Cash generated from operations per unit of capital employed is an important indicator of VAR and is used in the computation of market value (MV) for shareholders where discounted cash flow (DCF) and relative valuation models inflate or deflate corporate stock market values depending on the extent to which current cash earnings are improving to reduce or increase VAR. Movements in the share of cash extracted per unit of sales revenue reveal the extent to which corporate strategy and stakeholder arbitrage are modifying the pattern of cash extraction. 
Fig 2: Pyramid of ratios deconstructing corporate cash return on capital employed.

INCOME STATEMENT

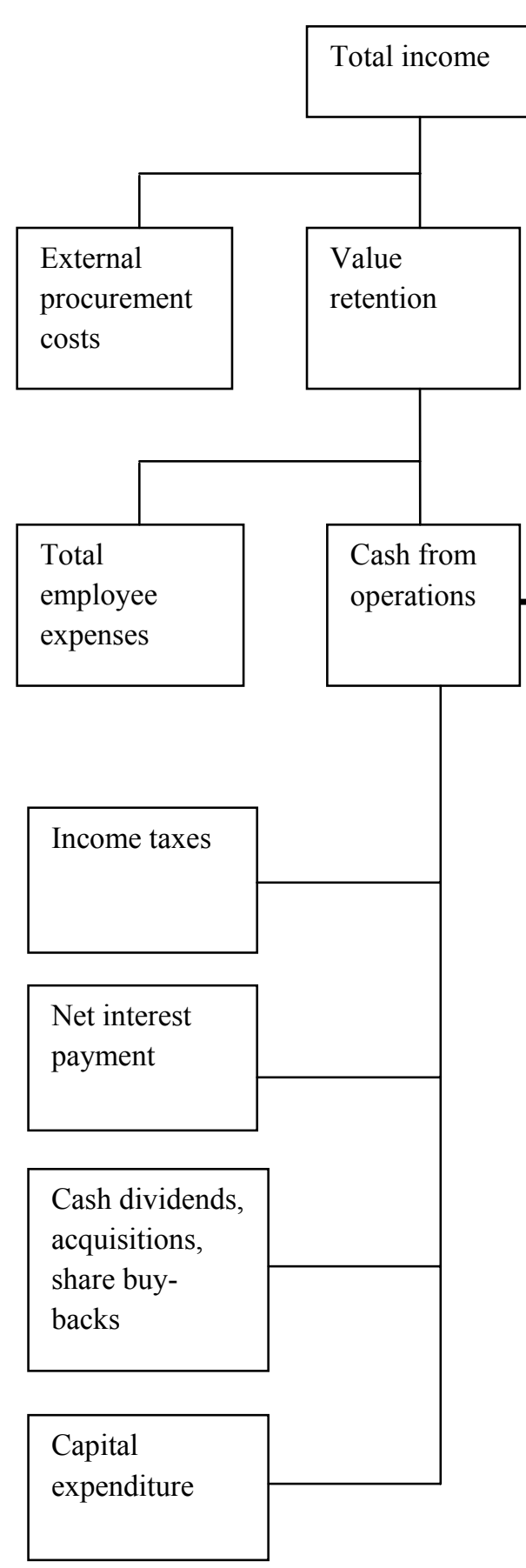

PERFORMANCE RATIO

BALANCE SHEET

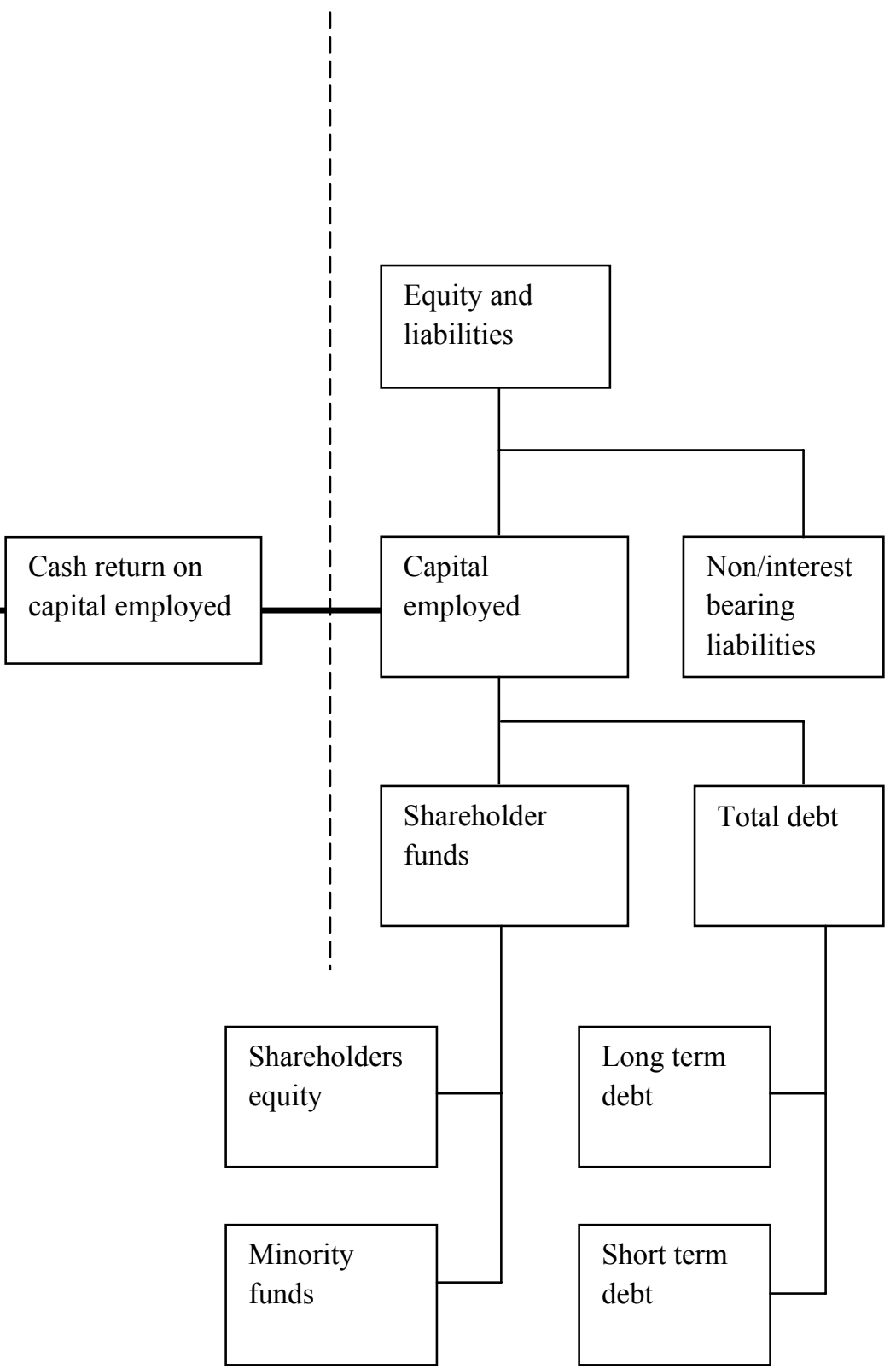

In table 1 below we show the share of cash extracted out of total income for the S\&P 500 constituent list and for the 'survivor group' that is 213 firms that remain in the constituent list throughout the period 1990 to 2006. This analysis reveals that large US corporations 
increased the share of cash extracted out of total income from an average 15-16 per cent in 1990 to roughly 21 per cent at the end of the decade. Throughout the period 1990-2000 the average S\&P 500 company reduced total cost (procurement and total employee expenses) in income from 85 to 80 per cent. It is also clear that there are limits to cash extraction when, in recent years, the share of cash extracted out of total income has remained relatively stable in the range 20-22 per cent.

Table 1

S\&P 500 constituents and survivors cash extracted out of total income 1990 to 2006

Source: S\&P, Washington 10K's and Thomson Financial

\begin{tabular}{|c|c|c|}
\hline & S\&P 500 Constituents & S\&P 213 Survivors \\
\hline & Cash in Total Income & Cash in Total Income \\
\hline 1990 & 15.4 & 16.2 \\
1991 & 14.9 & 15.7 \\
1992 & 15.5 & 16.1 \\
1993 & 16.7 & 17.2 \\
1994 & 17.9 & 18.0 \\
1995 & 19.0 & 19.1 \\
1996 & 19.1 & 19.0 \\
1997 & 19.9 & 20.0 \\
1998 & 20.6 & 20.6 \\
1999 & 21.1 & 20.9 \\
2000 & 20.8 & 21.2 \\
2001 & 19.1 & 19.5 \\
2002 & 19.9 & 19.6 \\
2003 & 20.1 & 19.8 \\
2004 & 20.3 & 20.2 \\
2005 & 21.2 & 20.4 \\
2006 & 21.4 & 20.8 \\
\hline
\end{tabular}

Notes: Cash is earnings before interest, tax, depreciation and amortisation (EBITDA). During the period 1990 to 2006213 firms survived continuously in the S\&P 500 index.

S\&P 500 companies have managed to stretch additional cash out of total income during the last two decades but this has been offset by an increase in capital intensity (long-term debt and shareholder funds) relative to total income. In figure 3 we graph the index of total income and capital employed for the period 1990 to 2006. During this period total capital employed in the S\&P 500 group increased four times in contrast to income which increased by a factor of two and a half. Although cash extraction (cash share in total income) increased during the period this was offset by increased balance sheet capitalisation (capital employed per dollar 
of total income) and this, significantly, puts a brake on the reported cash ROCE. In the years prior to the last US recession in 2000 the cash ROCE in the S\&P 500 reached a peak of 26-27 percent and although growth has returned in recent years the cash ROCE did not recover lost ground but stalled at just over 20 percent (see table 2)

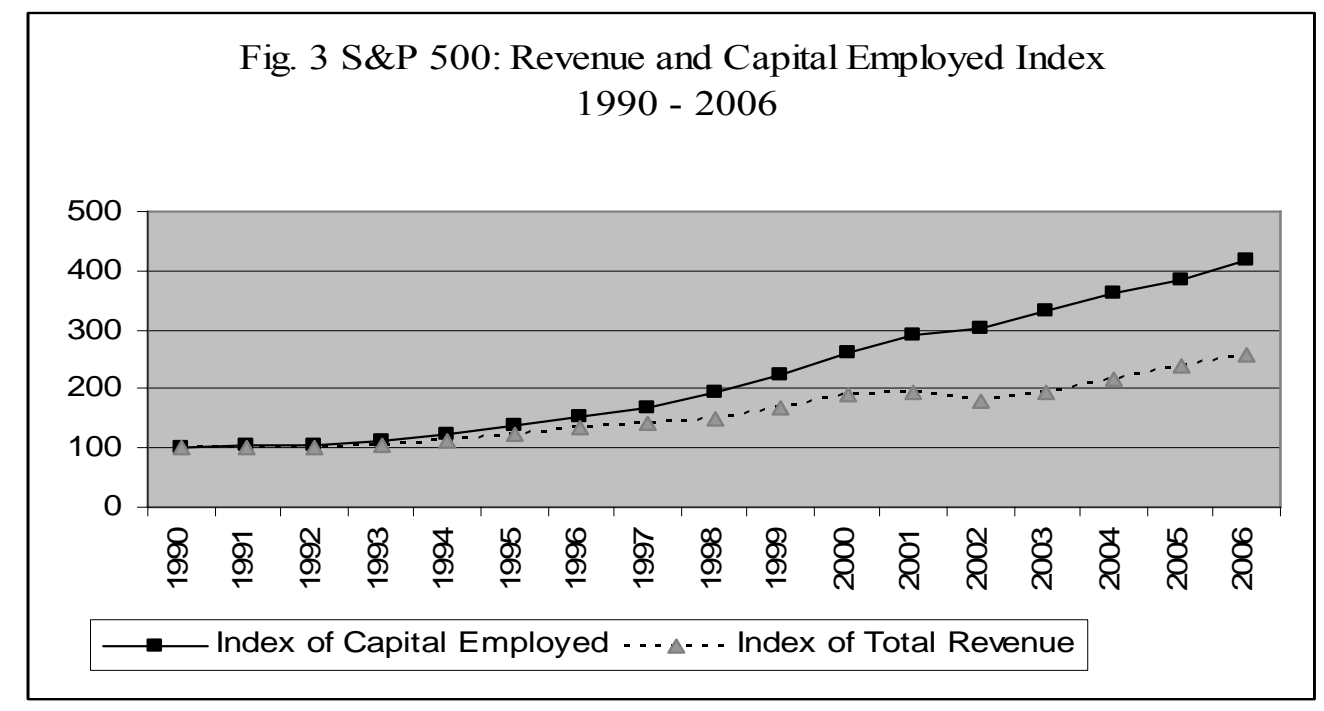

Source: S\&P, Washington.

See footnote for definition of capital employed ${ }^{1}$

It is possible to construct a convincing narrative about the limits of strategy and management's ability to transform financial performance in the S\&P500. This type of account is however located in an orthodox left to right framework of analysis which we have described in figure 1. In this conventional framework the strategy process and associated elements combine along a left to right continuum where strategy, stakeholder arbitrage and resulting corporate financial performance either delivers or frustrates value creation. In a financialized account Andersson et al (2007) argue that it is possible to construct an alternative perspective of strategy as both value creation and value absorption.

\footnotetext{
${ }^{1}$ The data we employ to construct the dataset employs a definition of capital employed as: shareholders equity and long term debt. Our computation of capital employed excludes short term debt and minority, which amounts to around 40 per cent of total capital employed as at the year end 2006.
} 
Table 2: S\&P 500 constituents and survivors cash ROCE 1990 to 2006

\begin{tabular}{|c|c|c|}
\hline & $\begin{array}{c}\text { S\&P 500 } \\
\text { Cash ROCE }\end{array}$ & $\begin{array}{c}\text { S\&P 213 } \\
\text { Cash ROCE }\end{array}$ \\
\hline 1990 & 23.1 & 24.1 \\
1991 & 21.3 & 22.5 \\
1992 & 22.7 & 24.1 \\
1993 & 23.4 & 24.9 \\
1994 & 24.1 & 26.0 \\
1995 & 25.7 & 27.3 \\
1996 & 25.0 & 26.5 \\
1997 & 25.3 & 27.4 \\
1998 & 23.7 & 26.1 \\
1999 & 23.3 & 25.2 \\
2000 & 22.6 & 25.0 \\
2001 & 18.8 & 21.8 \\
2002 & 17.8 & 19.8 \\
2003 & 17.7 & 19.4 \\
2004 & 18.0 & 19.6 \\
2005 & 19.7 & 21.0 \\
2006 & 19.7 & 21.0 \\
\hline
\end{tabular}

Source: S\&P, Washington 10K's and Thomson Financial

Notes: Cash ROCE is cash is earnings before interest, tax, depreciation and amortisation (EBITDA) divided into total capital employed (long-term debt plus shareholder equity). During the period 1990 to 2006213 firms survived continuously in the S\&P 500 index.

In the following section we consider how fair value reporting and an active market for corporate control combine to inflate the value of corporate sector balance sheets ahead of cash earnings as market value is absorbed into corporate sector accounts.

\section{Value absorption in the S\&P 500}

In the US corporate sector there is an active market for corporate control (Manne, 1965) and significant churn in the ownership of corporate assets by value. During the period 1996 to 2006 the value of M\&A deals in the US corporate sector amounted to $\$ 10.3$ trillion which was roughly equivalent to the market value of outstanding share capital of the S\&P500 as at the end of December 2006. 
Table3: Value of M\&A deals in the US (1996 to 2006)

\begin{tabular}{|c|c|c|c|}
\hline \multicolumn{4}{|c|}{ USA } \\
\hline & Deals & Value & $\begin{array}{c}\text { Value } \\
\text { per deal } \\
\text { \$ mill }\end{array}$ \\
Year & No. & \$ mill & 126.2 \\
\hline 2006 & 11,750 & 1,483 & 112.1 \\
2005 & 11,013 & 1,235 & 80 \\
2004 & 10,296 & 823 & 64.4 \\
2003 & 8,232 & 530 & 59.6 \\
2002 & 7,411 & 442 & 79.9 \\
2001 & 8,545 & 683 & 114.1 \\
2000 & 11,123 & 1,269 & 144.1 \\
1999 & 9,628 & 1,387 & 159.5 \\
1998 & 8,047 & 1,283 & 86 \\
1997 & 7,848 & 675 & 80 \\
1996 & 5,862 & 469 & 103 \\
\hline Totals & 99,755 & 10,279 & 10 \\
\hline
\end{tabular}

Source: Mergerstat, http://www.mergerstat.com/new/indexnew.asp \& Thomson Financial (Communication March 2007)

For most of this period US firms were required to account for their corporate acquisitions using the purchase method, that is, at their 'fair' or market value. Since the year 2000 all corporate acquisitions in US are accounted for using the purchase method (SFAS 141 Business Combinations). Up until the year 2000 it was possible for the acquiring firm to either pool its accounts with those of the acquired firm or employ the purchase method. Pooling involves combining the income and balance sheet statements rather than stating balance sheet value at fair value, so that, apart from minor adjustments, the income statements and balance sheets of two merging firms were simply aggregated. SFAS 141 now treats the corporate sector as if it were an asset management activity where capital market related financial transactions are frequently marked to market (Penman, 2006). In the five year period since adoption of the purchase method the US corporate sector has been required to absorb roughly $\$ 6.5$ trillion of fair value into their balance sheets at a time when the cash to market value ratio of S\&P 500 firms was running at 8:1. On the day an acquisition is accounted for the acquired company balance sheet is adjusted to reflect the market value of the deal which includes any additional deal premium which, in the S\&P 500, currently averages out at 27 per cent (Morgan, Stanley, 2006.) It is the market value of the acquired company balance sheet which is shown in the acquiring firm's consolidated accounts and in 
general this tends to inflate balance sheet capitalization ahead of cash earnings after the acquisition is accounted for at fair value.

Figure 4

S\&P 500: Cash ROCE and Cash MV ratios 1990 to 2006

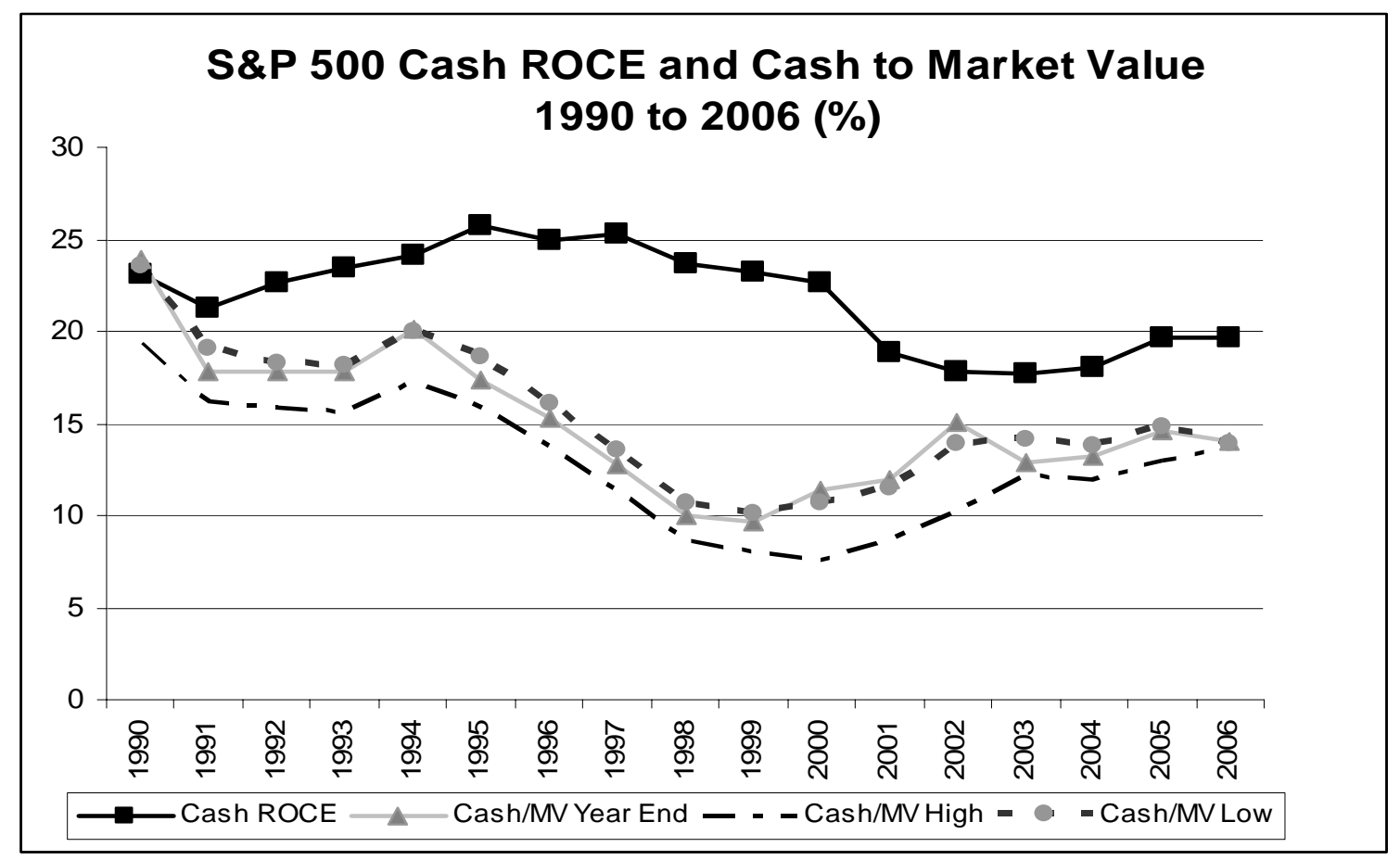

Source: S\&P, Washington 10K's and Thomson Financial

Notes: Cash is cash from operations (EBITDA-earnings before interest, tax, depreciation and amortisation). Capital employed is long-term debt plus shareholder equity and market value year-end, high and low share price multiplied by total shares outstanding.

Figure 4 shows the reported cash ROCE and the average, high and year end cash to market value ratio for S\&P500 survivors over the period 1990 to 2006. This chart reveals a persistent gap between the reported cash ROCE in the S\&P 500 survivor group and the cash MV ratio of this same group of firms. The MV absorption gap (the difference between reported cash ROCE and MV ROCE) represents the negative impact of absorbing the acquired firm's cash to market value ROCE into the acquirer's accounts. For the average S\&P 500 firm consolidating the acquisition at market value will depress reported cash ROCE and increase value at risk (VAR). To close the gap and reduce VAR acquiring company managers are forced to extract additional cash out of income and/or reduce inflated balance sheet capitalization. Stretching additional cash out of income can improve the cash numerator in 
the ratio but this may take time to execute and, as we have already noted, there is evidence to suggest that cash extraction rates in the S\&P 500 group have reached at plateau in recent years (see table 2).

If there are factors limiting the rate of cash extraction out of income this shifts the burden of adjustment onto the denominator of the cash ROCE ratio, namely capital employed. Our argument is that share buy-backs play a significant role in correcting conventional VAR metrics because they have the desired effect of progressively reducing capital employed (reported as shareholder funds) in the denominator of the cash ROCE ratio. Share buy-backs have become a significant cash transaction in recent years exceeding conventional dividends. During the period March 1998 to June 2007 the value of share buy-backs in the S\&P 500 came in at $\$ 1.9$ trillion and conventional cash dividends $\$ 1.6$ trillion and in the same report Standard and Poor's reveal that many S\&P 500 firms are retaining share buy-backs as for treasury stock.

'the increased buyback levels were unique in that the additional shares were not being used for options or M\&A, but rather were being put into corporate treasuries, creating share count reduction (SCR)" (Standard and Poor's, 2007:3)

On a cost basis the net value of banked treasury stock in the S\&P 500 amounted to $\$ 1,002$ billion and equivalent to $11 \%$ of outstanding market value of the S\&P 500 as at July $12^{\text {th }}$ 2007. If these shares had been marked to market in the balance sheet they would have a fair value of $£ 1,708$ billion as at $12^{\text {th }}$ July 2007 (S\&P, 2007: 6). Although share buy-backs distribute cash to shareholders banked treasury shares represent a significant asset which managers can employ to lever finance for further M\&A deals. If a firm's stock price inflates banked treasury shares accumulate a holding gain which can be realised when shares are traded, for example, to finance another corporate acquisition.

The steady buy-back of share capital by S\&P500 firms represents a serious commitment of corporate cash resources where the accumulated treasury balance is accounted for as reducing shareholder funds thereby helping to boost reported cash ROCE. Although this accounting manoeuvre helps to flatter reported cash ROCE a strong case could be made for treating treasury stock (the purchase of one's own outstanding share capital) as an asset that is recorded under cash and marketable securities like any other corporate stockholding. 
Share buy-backs not only flatter the cash ROCE and (possibly) accumulate holding gains they help to inflate earnings per share (EPS). In 2006 roughly 20\% of S\&P 500 firms increased EPS by at least $4 \%$ as a result of share buy-backs and in 2006 the share count of the S\&P 500 dropped by $1.5 \%$ (Standard and Poor's, 2007)

Figure 5: Strategy as value absorption: process, elements, direction

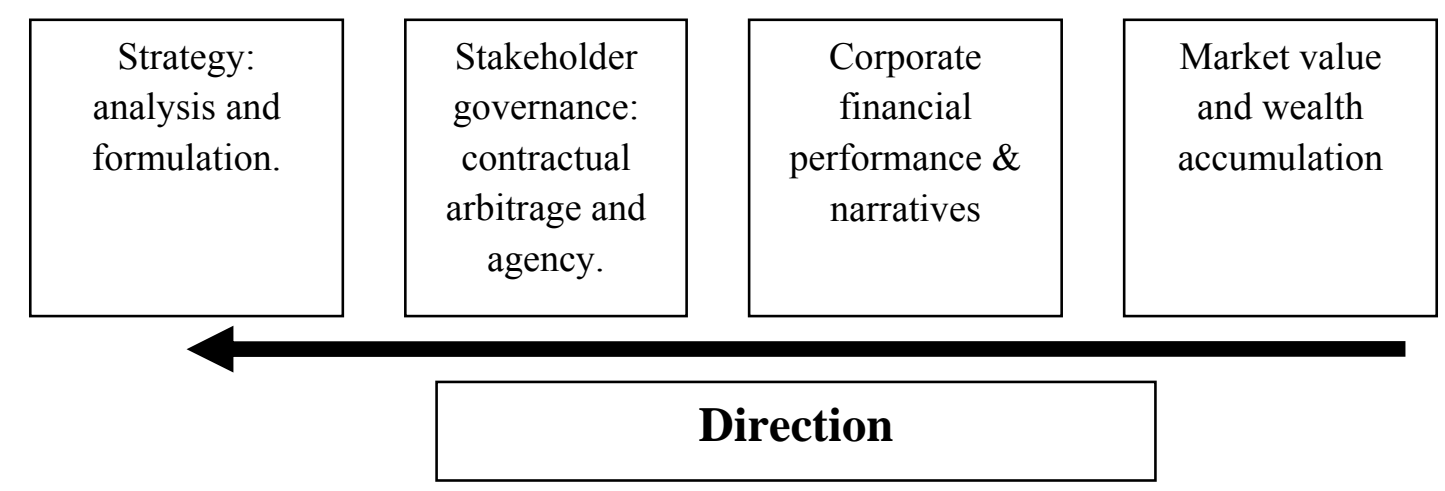

When US corporate sector engages in capital market transactions these now have to be accounted for at fair value (FASB, SFAS 157) and of particular significance is how US firms account for business purchases (FASB, SFAS 141). These transactions now blend the product of wealth accumulation (market value) with current income circuits and reverse the direction of flow because MV is absorbed onto corporate balance sheets. Figure 5 reveals value absorption as a right to left process which has the potential to undermine corporate financial metrics such as the cash ROCE. In these circumstances value absorption promotes the need for further contractual renegotiation, financial arbitrage between stakeholders and adjustment in strategic priorities. In the following section we reveal how financialization, is directing a strategy as value creation and value absorption in Procter and Gamble (P\&G). P\&G's acquisition of Clairol, Wella and more recently Gillette had a profound impact on reported corporate financials in $\mathrm{P} \& \mathrm{G}$ forcing cost reduction and a significant programme of share buy-backs. The Procter and Gamble case also reveals the difficulty in constructing narratives about strategy, corporate performance and value creation when reported accounting numbers embody value creating and value absorbing transactions. 


\section{Financialization directing strategy: The case of Procter and Gamble.}

Where stock market wealth accumulation blends with current income in corporate sector accounts this financializes strategy and modifies corporate governance priorities (see Andersson et al, 2008). In financialized accounts current income and wealth accumulation circuits are impacting simultaneously on reported financials in the US corporate sector and strategy is a struggle to both create and absorb market value for shareholders.

To further develop this argument we employ the case of Procter and Gamble to reveal financialization as both value creation and value absorption. Procter and Gamble is a branded goods manufacturer operating in: fabric and home care, razors, beauty and healthcare and baby and family products. In 2007 it had sales revenues of $\$ 76$ billion and a quoted market value of approximately $\$ 250$ billion. In the last 5 years $P \& G$ increased the scale of its operations through a series of acquisitions including the purchase of Clairol, Wella and more recently Gillette. The latter acquisition of Gillette, a complementary branded goods business, was a significant move because Gillette had annual sales of roughly $\$ 10$ billion and cash earnings of $\$ 3.2$ billion on capital employed of $\$ 5$ billion. On the day of acquisition, October 1st 2005, Gillette was valued at $\$ 53.4$ billion and it is this value, not the $\$ 5.0$ billion of historic balance sheet capital employed, which is accounted for in the consolidated P\&G balance sheet. Gillette's cash ROCE prior to its acquisition was $60 \%$ but after the purchase it drops to $6 \%$ when 'marked to market' and consolidated into P\&G's accounts. The scale of the Gillette purchase, coupled with the high market value to cash ratio of this deal, had a significant adverse impact on P\&G's consolidated accounts, financial performance and VAR.

We start with a brief financial review of Procter and Gamble before and after the acquisition of Gillette revealing the extent to which revenue trajectories and costs structures were transformed. Starting with P\&G's income trajectory we note that the years 2001 and 2002 mark a break the past because the acquisition of Clairol and Wella set revenue on a new higher rate of growth. 


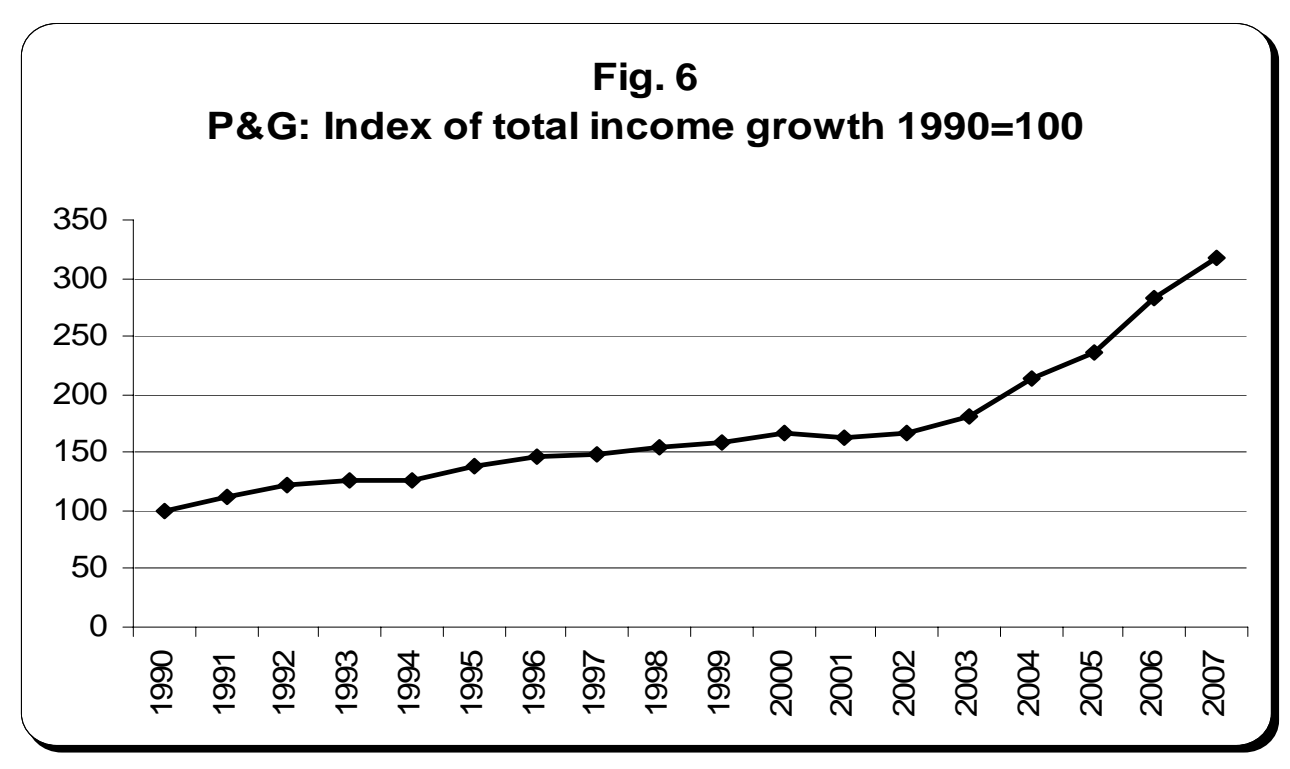

Source: Standard and Poor's, Washington, US and EDGAR SEC dataset P\&G 10K's

In 2005 the acquisition of Gillette boosts total income by roughly $\$ 10$ billion and helps to maintain the growth pattern established after 2001 with the acquisition of both Wella and Clairol. Although these acquisitions shift growth onto a new trajectory they did not significantly transform cost structures and thereby also the share of cash extracted out of income for $\mathrm{P} \& \mathrm{G}$.

Fig. 7

P\&G: Cash as a share of total Income

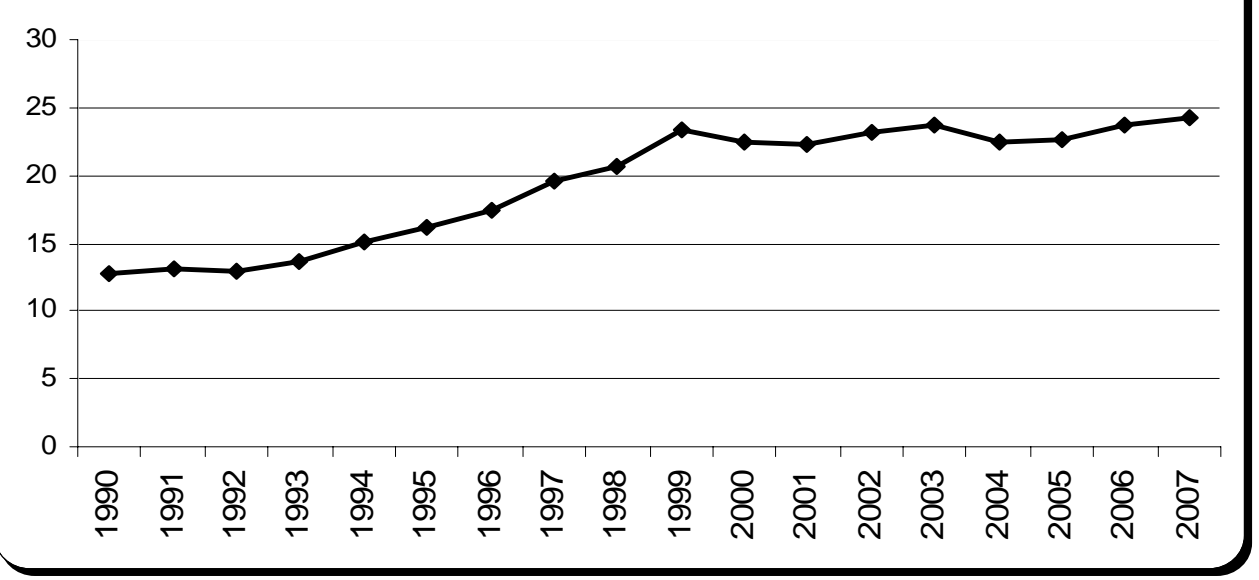

Source: Standard and Poor's, Washington, US and EDGAR SEC dataset P\&G 10K's

Note: Cash is defined as EBITDA (earnings before interest, tax, depreciation and amortisation) and this is divided into total income. 
Throughout the 1990's P\&G steadily takes cost out of its operations and increases the share of cash generated out of total income from 13 to 23 per roughly doubling the share of cash in income. However figure 7, reveals that the addition of Clairol, Wella and Gillette into P\&G's operations did not contribute to any further significant increase in the share of cash extracted out of income. It can reasonably be assumed that Clairol, Wella and Gillette had, in similar fashion to $P \& G$, reduced their cost structures during the $1990 \mathrm{~s}$, for example, Gillette's share of cash in income fell from 80 to 70 percent during the 1990s before it was acquired by $P \& G$ in 2005. P\&G's acquisitions enhanced its growth trajectory but they did not transform the share of cash extracted out of total income. This is significant because all three acquisitions contributed to inflating P\&G's balance sheet capitalization which then impacts negatively on the reported cash ROCE. P\&G's purchase of Clairol, Wella and Gillette were all accounted for at 'fair value' following the SFAS 141 and this unsettles VAR because capital employed per dollar of sales accelerated ahead of cash extracted per dollar of sales.

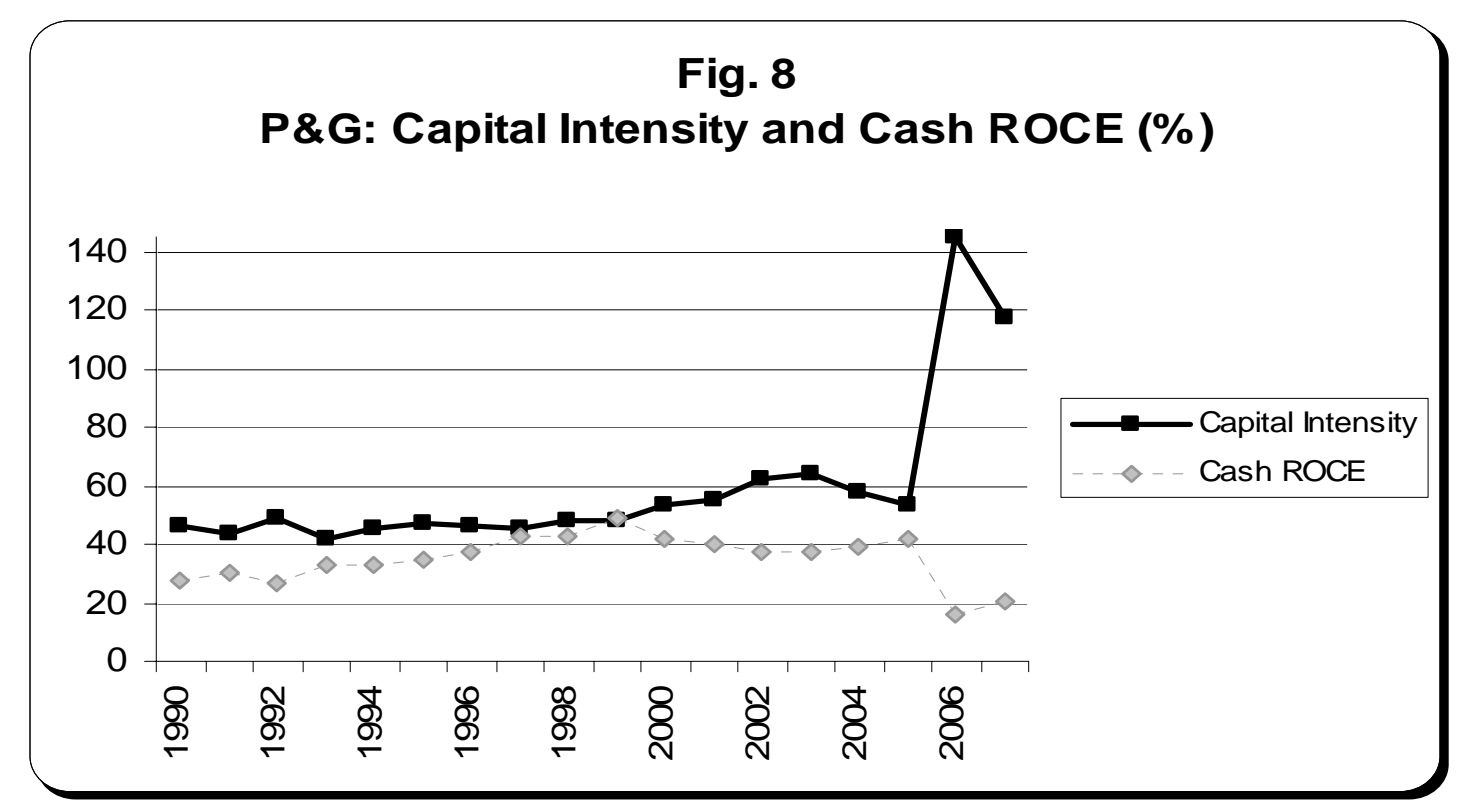

Source: Standard and Poor's, Washington, US and EDGAR SEC dataset P\&G 10K's

Notes: capital intensity index (CII) is measures as total income divided into total capital employed (which is total long-term debt plus shareholder funds)

During the 1990s P\&G managers do secure a reduction in the share of total costs in income thereby boosting the cash residual whilst capital intensity is maintained at a relatively steady level of 45-50 cents of capital employed per \$ of total income. This favourable combination 
boosts reported cash ROCE from 27 per cent at the start of the 1990s to 40 per cent at the end of the decade. To put this financial achievement into perspective P\&G, with a ROCE of 27 percent in 1990, was located in the top forty per cent of the S\&P 500 group of firms and at the end of the decade P\&G's cash ROCE put it in the top twenty per cent.

The period after 2000 marks a break with the past because $P \& G$ acquisitions absorbed MV into the balance sheet inflating capitalisation ahead of cash earnings. During the 1990's P\&G employed 50 cents of capital employed per dollar of total income and after 2000 this increases to 60 cents and ultimately 140 cents of capital employed per dollar of total income after the acquisition of Gillette. This inflated balance sheet collapses the reported cash ROCE from forty to twenty percent.

Depending on the scale of an acquisition, and its market value relative to the acquirers own balance sheet capitalization, market value absorption generally undermines reported shareholder value metrics. In $\mathrm{P} \& \mathrm{G}$ shareholder value is increasingly at risk because the ratio of cash to balance sheet capital employed was halved. To correct the cash ROCE and bring it back to its previous level of 40 per cent would require $P \& G$ to reduce total costs in income by at least twenty percent. Cost reduction is a strategic priority for $P \& G$ after its acquisition of Gillette as the following quote from the company annual 10-K reveals.

We've delivered nearly $\$ 400$ million in cost savings through GBS and we believe we can achieve another $\$ 300$ million by the end of the decade as we move more business activities into GBS. In Product Supply, we're concentrating on applying our purchasing expertise and scale to more segments of our spending pools, which we believe can generate significant savings over the next three years. We'll also continue to improve R\&D productivity by generating more value from our "connect + develop" innovation partnerships and by leveraging innovation productivity technologies such as virtual modelling and simulation tools that take months out of product development programs and greatly reduce the required investments

(SEC, EDGAR , P\&G 10K, 2007:6)

http://www.sec.gov/Archives/edgar/data/80424/000095015207007152/127490aexv13.htm

These are significant initiatives including: product, procurement and labour market arbitrage to increase cash extracted out of income to boost the numerator in the cash ROCE. However these moves cannot deliver immediate transformation because product market interventions and adjustments to the configuration of procurement value chains will necessarily take time 
to structurally implement. Moreover in a competitive market it is not clear to what extent cost savings will be given away to households in the form of price cuts. Alternatively stretching cash out of income can provide additional financial leverage in the form of external debt financing which can be employed to reduce balance sheet capitalization through share buybacks.

Share buy-backs for treasury stock are purchased at their market value and can be banked, employed: to fund employee share option benefit schemes, corporate acquisitions or retired to reduce outstanding share count. The significance of buying back shares and holding these in treasury is that the cost of stock repurchased is treated as a deduction against shareholder funds thereby reducing reported shareholder funds and thus capital employed. Where share buy-backs are funded by debt financing this debt can be reduced over a period of time as and when principal repayments are made out of cash. Significantly share buy-backs are not treated in the balance sheet as assets under cash and marketable securities even though treasury stock is an "invisible asset" because it can be utilised as a hedge for granted share options as well as accrue holding gains too provide financial leverage when financing further acquisitions.

Figure 9 is taken from the annual report and accounts submitted by $P \& G$ to the Securities and Exchange Commission (SEC), in the US, and it reveals that a sum of $\$ 38.8$ billion of treasury stock had been repurchased at the end of the 2007 financial year. This extract reveals that treasury stock is accounted for as reducing shareholder equity and capital employed in the balance sheet. P\&G has increased its share buy-back (SBB) programme in recent years with 80 per cent accounted for after the financial year 1999/2000 (see fig. 10). The value of accumulated treasury stock reported in P\&G's balance sheet in 2007 was equivalent to 16 per cent of outstanding total stock market value in that year. 
Fig. 9 Extract from P\&G Annual Report 2007

\begin{tabular}{|c|c|c|}
\hline SHAREHOLDERS' EQUITY & 2007 & 2006 \\
\hline Convertible Class A preferred stock, stated value $\$ 1$ per share (600 shares authorized) & 1,406 & 1,451 \\
\hline Non-Voting Class B preferred stock, stated value $\$ 1$ per share ( 200 shares authorized) & - & - \\
\hline Common stock, stated value $\$ 1$ per share (10,000 shares authorized; issued: $2007-3,989.7,2006-3,975.8)$ & 3,990 & 3,976 \\
\hline Additional paid-in capital & 59,030 & 57,856 \\
\hline Reserve for ESOP debt retirement & $(1,308)$ & $(1,288)$ \\
\hline Accumulated other comprehensive income & 617 & $(518)$ \\
\hline Treasury stock, at cost (shares held: $2007-857.8,2006-797.0$ ) & $(38,772)$ & $(34,235)$ \\
\hline Retained earnings & 41,797 & 35,666 \\
\hline TOTAL SHAREHOLDERS' EQUITY & 66,760 & 62,908 \\
\hline TOTAL LIABILITIES AND SHAREHOLDERS' EQUITY & 138,014 & 135,695 \\
\hline
\end{tabular}

http://www.sec.gov/Archives/edgar/data/80424/000095015207007152/127490aexv13.htm (page 51)

Fig. 10

P\&G: Accumulated share buy backs (bill)

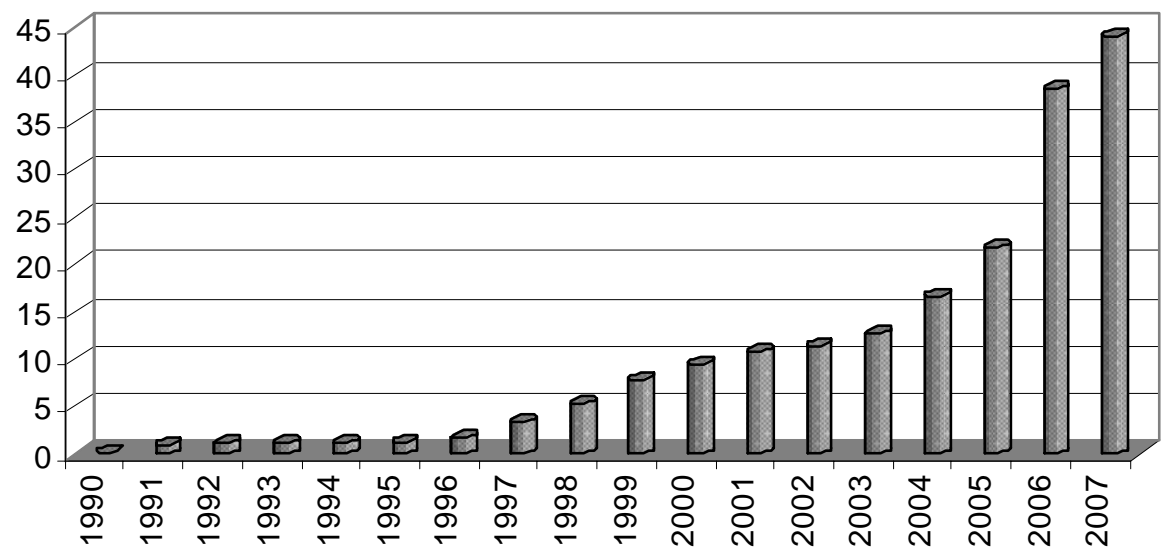

Source: Standard and Poor's, Washington, US and EDGAR SEC dataset P\&G 10K's

P\&G's SBB programme has utilised a significant amount of available corporate cash and the pattern of share buy-backs is set to continue with $P \& G$ managers recently announcing their intention to repurchase a further \$24-30 billion of outstanding share capital over the next 3 financial years ending 2010 . 
Total share repurchases in 2007 were $\$ 5.6$ billion, of which $\$ 0.3$ billion were made as part of our publicly announced share repurchase plan in connection with the Gillette acquisition. Total share repurchases in 2006 were $\$ 16.8$ billion, nearly all of which were made as part of our publicly announced share repurchase plan. We completed the announced share buyback program in July 2006 and purchased a total of $\$ 20.1$ billion of shares under this program. In fiscal years 2008 to 2010 , we expect to repurchase $\$ 24-\$ 30$ billion of Company shares at a rate of $\$ 8-\$ 10$ billion per year.

(SEC, EDGAR, P\&G 10K, 2007:43)

Over the period 1990 to 2007 strategic priorities in $P \& G$ have changed and this is reflected in the modified pattern of cash distribution to various stakeholder groups. If we aggregate discretionary cash distributed to fund: capital expenditure, cash acquisitions, share buy-backs, and cash dividends for the two periods 1990 - 1999 and $1999-2007$ the changed priorities are revealed.

Table 4: P\&G discretionary cash distribution over two distinct periods

\begin{tabular}{|l|c|c|c|c|c|}
\hline & $\begin{array}{c}\text { Total all } \\
\text { categories }\end{array}$ & $\begin{array}{c}\text { Capital } \\
\text { Expenditure }\end{array}$ & $\begin{array}{c}\text { Cash } \\
\text { Acquisitions }\end{array}$ & $\begin{array}{c}\text { Share } \\
\text { Buy- } \\
\text { Backs }\end{array}$ & $\begin{array}{c}\text { Cash } \\
\text { Dividends }\end{array}$ \\
$1990-1999$ & 100 & 45.8 & 17.7 & 13.4 & 23.1 \\
$2000-2007$ & 100 & 21.3 & 17.1 & 38.8 & 22.8 \\
\hline
\end{tabular}

Source: Standard and Poor's, Washington, US and EDGAR SEC dataset P\&G 10K's

Note: Discretionary cash is that available after tax and net interest charges have been deducted.

Table 4 adds up all the discretionary cash $P \& G$ has used to finance capital expenditure relative to that which has been distributed to shareholders as: cash acquisitions, share buybacks and cash dividends. In the first period the pattern of discretionary cash distribution was split equally between capital expenditure and payments to shareholders. In the second period the balance shifts towards shareholders who now take roughly 80 percent of discretionary cash resources. The share of cash distributed to finance cash acquisitions and pay cash dividends remained relatively stable across the two time periods at $17-18$ percent and 23 percent respectively. In 1990 and at the start of the period share buy-backs account for 13 percent of discretionary cash paid to shareholders but this increases to 39 percent by the end 
of financial year 2007. Financialization is directing strategy in $P \& G$ and stakeholder contracts modified by a process of financial arbitrage in order to secure value creation and accommodate value absorption. Managers must maintain or increase the growth rate in cash earnings out of income and combine this with a programme of share buy-backs to progressively align balance sheet capitalization with cash earnings. If we assume PG's cash earnings grow at their current compound rate of 6 per cent for four years and the company generates sufficient cash to finance $\$ 24$ billion of share buy-backs then, by 2011, reported cash ROCE will be back to $37 \%$.

As $P \& G$ executes its share buy-back programme this will inflate cash earnings per share (CEPS) which is an important metric employed by analysts to compute the market price of the companies share capital. Standard and Poor's report that 'the impact of buybacks boosted EPS by at least 4\% for more than 20\% of the issues in 2006' (Standard and Poor's, 2007:1).

Share buy-backs also have a different quality than pure cash dividends. Once cash is paid to shareholders the firm loses control over the cash but with share buy-backs managers retain control over repurchased share capital and there are good reasons for banking shares as treasury stock in corporate accounts when share prices inflate (see Andersson et al 2007, Standard and Poor's, 2007). Shares repurchased in an earlier period for treasury stock, will by virtue of stock market inflation, accrue holding gains and Standard and Poor's have estimated the book versus market value of S\&P 500 treasury stock. In June 2007 the book value of repurchase shares in the S\&P 500 was $\$ 1$ trillion and their market value $\$ 1.7$ trillion which means there is an opportunity to realise $£ 600$ million of holding gains on exchange if this treasury stock were used to finance corporate purchases. Andersson et al (2006) cite the example of Adobe's purchase of Macromedia with treasury shares where the market value on exchange was one-third higher than the cost of acquiring the stock.

All of this presumes that product markets continue to grow and share prices inflate into the future. Value creation and value absorption are difficult to sustain when product markets turn down because this restricts the growth of cash earnings per dollar of capital employed and limits the rate at which share buy-backs can be maintained. Moreover if a product market recession combines with a fall in stock market values this will: erode holding gains, inflate goodwill impairment and gearing magnifying VAR. 


\section{Conclusion/ Discussion}

The orthodox literature on strategy in an era of shareholder value focuses on how process and elements combine in a left to right direction strengthening corporate financials in a quest for value creation. In this model of strategy for shareholder value creation the firm is located in 'productionist' framework where income, expenditure and balance sheet transactions circuits are substantially decoupled from the circuits of capital market wealth accumulation. In a financialized account we argue that strategy in an era of shareholder value is a struggle to deliver value creation and accommodate value absorption.

In an earlier period it was possible to choose how to account for a corporate purchase either it was 'pooled' or 'marked to market'. In recent years the menu of options has been reduced and the accounting regulations governing corporate-capital market transactions promote 'fair value reporting'. The regulatory objective of US accounting boards such as the Finance Accounting Standards Board (FASB) has been to make the corporate sector in the image of asset management activity where transactions are continually marked to market so as to reflect the return to shareholder investors.

Accounting for the market value of capital market transactions, particularly that of corporate purchases, is significant because value absorption will inflate balance sheet ahead of cash earnings. This outcome is revealed in the case of P\&G's acquisition of Gillette which halved the reported cash ROCE after the market value of the transaction was accounted for in 2005 . Financialization is directing strategy in $P \& G$ and financial arbitrage modifying stakeholder claims as managers struggle to maintain value creation and accommodate value absorption. Our evidence on the S\&P 500 and the specifically P\&G suggests that there are limits to cash extraction out of income because, in recent years, this has remained on a plateau. Attention has instead turned towards employing corporate cash to lever additional finance which in turn is being used to increase share buy-backs.

Share buy-backs now exceed conventional divided payments out of corporate cash in the S\&P 500 this may be due to the fact that share buy-backs have additional qualities that make this application of corporate cash an attractive option. Share buy-backs give cash to shareholders but preserve management control over shares repurchased which can be employed to fund managerial remuneration and incentive schemes, boost reported earnings per share and attract holding gains by virtue of stock market appreciation. Because treasury 
stock is accounted for as reducing capital employed this also helps to progressively inflate reported cash ROCE and reduce VAR after market value has been absorbed into the balance sheet.

Financialization is directing strategy in an era of shareholder value because value creating and absorbing transactions are forcing modifications to stakeholder financial settlements. The orthodox left to right schematic of strategy as a process $\rightarrow$ elements $\rightarrow$ direction needs to be supplemented to include right to left connections. That is we need to understand how the financial numbers reported by companies, for example cash ROCE, are the product of value creating and value absorbing initiatives where current income streams and wealth accumulation are blended in corporate financial statements.

Our argument is that financialization is directing strategy and that the connection between process and elements is bipolar on the one hand value creation (left to right) and the other value absorption (right to left). Accounting numbers embody the outcome of value creating moves and reactions to value absorption both of which are acting simultaneously on reported corporate financials. And because reported financials in the S\&P 500 blend the product of both current income and wealth accumulation this, we believe, has implications for frameworks of analysis that employ accounting numbers to explore left to right relations or construct critical narratives about corporate performance and value. 


\section{References}

Andersson, T., Haslam, C and Lee, E. (2006). 'Financialized accounts: Restructuring and return on capital employed in the S\&P 500', Accounting Forum, 30 (1): 21-41.

Andersson, T., Haslam, C., Lee, E and Tsitsianis, N. (2007). 'Financialized accounts: A stakeholder account of cash distribution in the S\&P 500 (1990-2005)'. Accounting Forum 31 (3):217-232.

Andersson, T., Haslam, C., Lee, E and Tsitsianis, N. (2008). 'A Financialized account of corporate governance' in Strange, $\mathrm{R}$ and Jackson $\mathrm{G}$ (eds). Governance and International Business'Vol.15. AIB-UKI and Palgrave Macmillan.

Coase, R. (1937). 'The nature of the firm'. Econometrica, 4: 386-405.

Coase, R. (1991). 'Contracts and the activities of firms'. Journal of Law \& Economics 34: 451-52.

Cornell, B. and Shapiro A. (1987). 'Corporate stakeholders and corporate finance'. Financial Management Spring: 5-14.

Cowling, K. and Sugden R. (1998). 'The essence of the modern corporation: markets, strategic decision making and the theory of the firm'. The Manchester School, 66, (1):59-86.

Cutler A, Hindess,B. and Hurst, P. (1978). Marx's 'Capital' and Capitalism Today, Vol.2 Ch.8. London, Routledge and Kegan Paul.

Deeg, R. and O'Sullivan, M. (2006) 'The Financialization of Europe: The Evolution of Finance Capital in Britain, France, Germany, and Italy'. American Political Science Association, Marriott, Loews Philadelphia, and the Pennsylvania Convention Center, Philadelphia, PA.

Financial Accounting Standards Board (FASB, 2001) SFAS 141 http://www.fasb.org/st/summary/stsum141.shtml

Financial Accounting Standards Board (FASB, 2001) SFAS 157 http://www.fasb.org/st/summary/stsum157.shtml

Fligstein, N. (2004). 'The end of (shareholder value) ideology?' Institute for Research on Labor and Employment Working Paper Series Paper iirwps-116-05.

Freeman, R. E. (1984). Strategic Management: A Stakeholder Approach. Boston: Pitman.

Froud, J., Haslam, C ., Johal, S., and Williams, K. (2000). 'Financialization and shareholder value: Consultancy moves management promises'. Economy and Society 29(1): 80-120. 
Froud, J., Johal, S., Leaver, A. and Williams, K. (2006). 'Financialization and Straetgy: Narrative and Number's. Routledge, Taylor and Francis, London.

Hamel, G. and Stern J. (1995). 'Le court terme peut-il ruiner la vision à long terme'. L'Expansion Management Review. Décembre: 64-9.

Jensen, M. (1993). 'The modern industrial revolution: Exit and the failure of internal control systems'. The Journal of Finance July.

Kay, J. (1993). Foundations of Corporate Success, Oxford University Press.

Knight, F. H. (1921). Risk Uncertainty and Profit. Boston and New York, Houghton Mifflin Company.

Manne, H. G. (1965). Mergers and the market for corporate control. Journal of Political Economy 73: 110-120.

Martin, R. 2002. Financialization of Daily Life. Temple University Press: Philadelphia. 20.

Morgan Stanley. (2006). http://westlegalworks.com/presentations/m\&a2k6/panel1.pps\#1.

Penman, S. (2006). Financial Reporting Quality: Is Fair Value a Plus or a Minus? Paper presented at Information for Better Markets Conference Institute of Chartered Accountants in England and Wales December 18-19.

http://www.icaew.co.uk/index.cfm?route $=143928$

Phelan, S. E. and Lewin, P. (2000). Arriving at a strategic theory of the firm. International Journal of Management Reviews 2 (4): 305-323.

Porter, M. (1980). Competitive Strategy: Techniques for Analyzing Industries and Competitors Free Press: New York.

Porter, M. (1985). Competitive Advantage: Creating and Sustaining Superior Performance, Press: New York.

Prahalad, C. K. and Hamel, G.(1990). The core competence of the corporation. Harvard Business Review 68 (3): 79-91.

O'Sullivan, M. (2000). Contests for Corporate Control, Oxford University Press, Oxford.

Rappaport, A. (1986). Creating shareholder value: The new standard for business performance. The Free Press: New York.

Rossman, P and Greenfield, G. (2006). Financialization: New routes to profit, new challenges for trade unions. Labour Education, ILO Bureau for Workers' Activities: 142.

http://www.iufdocuments.org/www/documents/Financialization-e.pdf 
Rumfelt, R. P., Schendel, D.E, and Teece, D. J. (1994). Fundamental issues in strategy. Boston Mass, Harvard Business School Press.

Simon, H. (1991). Organizations and markets. Journal of Economic Perspectives. 5 (2): 28.

Standard and Poor's. 2007. S\&P 500: Buybacks and treasury shares the overlooked and hidden assets, McGraw-Hill, July 19.

http://www2.standardandpoors.com/spf/pdf/index/071907_BuybacksReport.pdf

Stewart, G. B. III. (1991). The quest for value: A guide for senior managers. New York; Harper Collins.

Stockhammer, E. (2004). Financialization and the slowdown of accumulation, Cambridge Journal of Economics, 28, 719-741.

Treynor, J. L. (1981). What does it take to win the trading game? Financial Analysts Journal, January/February: 55-60.

Williamson, O. E. (1975). Markets and Hierarchies: Analysis and antitrust implications. Free Press, New York.

Williamson, O. E. (1993). The logic of economic organization. In The Nature of the Firm: Origins, Evolutions and Development Williamson, O.E., Winter, S.G (Eds). Oxford University Press: New York, NY and Oxford. 